\begin{tabular}{l|c|c}
\hline ISSN: 0001-5113 & ACTA ADRIAT., & ORIGINAL SCIENTIFIC PAPER \\
AADRAY & $58(1): 105-116,2017$ & \\
\hline
\end{tabular}

\title{
Assessment of the effects of bisphenol-A as a disruptor on ionic regulation in Danio rerio zebrafish through a study of their chloride and prolactin cells
}

\author{
María I. BARASONA ${ }^{1}$, Ana MOLINA ${ }^{1 *}$, Alfonso BLANCO ${ }^{2}$, Nahum AYALA $^{1}$ \\ and Rosario MOYANO ${ }^{1}$ \\ ${ }^{1}$ Department of Pharmacology, Toxicology and Legal and Forensic Medicine. Veterinary \\ Faculty. University of Córdoba, Campus de Rabanales Carretera Madrid-Cádiz s/n, \\ Córdoba 14071, Spain \\ ${ }^{2}$ Department of Anatomy and Comparative Pathology and Anatomy. Veterinary Faculty. \\ University of Córdoba, Campus de Rabanales Carretera Madrid-Cádiz s/n, \\ Córdoba 14071, Spain \\ *Corresponding author, e-mail address: ft2moloa@uco.es
}

\begin{abstract}
Bisphenol A (BPA) is one of the chemicals produced in the largest volume in the world. It is commonly used as a component of plastics and food containers and can act as a xenoestrogen in humans. In view of the risk of exposure to it from the environment and diet, and basically as a water pollutant, the objective of our study was to assess possible effects on ionic regulation after exposure to BPA by means of a histopathological and morphometric study of the chloride and prolactin cells in zebrafish (Danio rerio) as an experimental model.

Twenty-five male 16-week old zebrafish (Danio rerio) were allocated randomly into 5 study groups ( $n=5 /$ group); a control group, and four groups, exposed for 2 weeks to a concentration of (1, $10,100$ and $1000 \mu \mathrm{g} / \mathrm{L})$ of BPA, respectively. After 2 weeks, the animals were sacrificed and samples of their gills and pituitary gland were immediately taken for their subsequent histopathological analysis.

Our results showed how, in the first study groups, lesions appeared in chloride cells, generating compensatory modifications in the prolactin cells, which were enough to maintain stability in the ionic exchange. As the exposure concentration increased, more serious histological modifications occurred. In the groups with the highest concentration (100 and $1000 \mu \mathrm{g} / \mathrm{L})$, the lesions were so severe that the prolactin cells underwent some degenerative processes, which probably prevented the compensatory action at gill level.
\end{abstract}

Key words: Danio rerio, Bisphenol A, zebrafish, ionic regulation, prolactin cells, chloride cells 


\section{INTRODUCTION}

Bisphenol A (BPA) is a component of, among other items, plastics and food containers, and it is one of the chemicals produced in the largest volume in the whole world (LANG et al., 2008), reaching high world production figures; in 2006, 3.8 million tons of it were produced (FITZGERALD et al., 2014). Changes in $\mathrm{pH}$, mechanical abrasions and heat, accelerate hydrolysis of the ester bond linking BPA molecules in polycarbonate plastic, and repeated washing of polycarbonate products causes BPA to easily leach out of products and spread it over the environment, even at ambient temperatures (HOWDESHELL $e$ al., 2003). It is a known fact that BPA is a weak oestrogenic chemical, which produces important effects in the male tract, mainly in testes, with a significant sperm decrease (BHANDARI et al., 2015; WISNIEWSKI et al., 2015). It is known that BPA acts on the anterior pituitary gland, stimulating PRL production by up to $50 \%$ of the maximal response obtained with $17 \beta$-estradiol (E2) from prolactin cells in the adult, inducing lactotrope proliferation (STOKER et al., 1999, RAMOS et al., 2003; VELASCO-MARINERO et al., 2011). Further, it has been reported that BPA induces gill modifications and severely alters chloride cells (MOHAMMED et al., 2013; FAHEEM et al., 2016). Prolactin cells regulate osmotic balance, stimulating processes involved in freshwater adaptation in the gill, kidney, and gut (PIERCE et al., 2007). These types of alterations in prolactin cells could be reflected in those changes in chloride cells. Several research works have reported prolactin cell participation in gill ionic regulation, because of which the serious modifications in chloride cells could induce a palliative prolactin cell reaction (BARTELS et al., 2015; INOKUCHI et al., 2015).

Many works have been focused on fish since, as they are aquatic inhabitants, they receive sewage or industrial effluents and agricultural runoff containing oestrogenic chemicals (HASSANIN et al., 2002). Zebrafish are suitable for assessing toxic effects because test protocols have already been established, including OCDE guidelines (OCDE 204, 210, 212), that recommend these fish for chemical toxicity assessments, as well as in Annex I of Directive 2010/63/EU, relative to the protection of animals used for scientific purposes.

With the aim of investigating in depth BPA toxicity, our objective was to evaluate the effects of BPA on ionic regulation through the study of gills and chloride cells and their possible relationship with prolactin cells by histological evaluation after 14 days of BPA exposure.

\section{MATERIAL AND METHODS}

A total of twenty-five 16-week old male zebrafish (Danio rerio), were used to carry out this research. The animals were distributed randomly into 5 groups ( $\mathrm{n}=5 /$ group), a control group, and four treated groups, which were exposed for 14 days (OCDE 204) to graded concentrations (1, 10,100 and $1000 \mu \mathrm{g} / \mathrm{L}$ ) of BPA (Sigma Aldrich $\left.{ }^{\circledR}\right)$, under flow-through conditions (10 water renewals/day) and photoperiod of 16 light hours: 8 dark hours. Water temperature was $26 \pm 1{ }^{\circ} \mathrm{C}$ and dissolved oxygen was maintained above $60 \%$ of saturation level by continuously aerating the test solution.

The study was carried out in the Experimental Animal Service at the University of Córdoba (Spain). All procedures were approved by the Animal Care Committee of the University of Córdoba, and in concordance with the European Regulations for the Protection of Experimental Animals (Directive 2010/63/EU).

After 2 weeks of exposure, zebrafish were sacrificed with an overdose of anaesthetic solution of tricaine methanesulfonate (MS-222 ${ }^{\circledR} 500$ $\mathrm{mg} / \mathrm{L}$; Sigma-Aldrich ${ }^{\circledR}$, St. Luis, EE.UU) buffered with sodium bicarbonate $(300 \mathrm{mg} / \mathrm{L}$; Sigma-Aldrich ${ }^{\circledR}$, St. Luis, EE.UU), and next samples of gills and pituitary gland were removed for histological analysis.

\section{Histological evaluation}

For the structural evaluation, samples were routinely processed for paraffin sections by fixing in 10\% formaldehyde, dehydrating in graded series of ethanol, immersing in xylol and embedding in paraffin wax. Every tenth section $(4 \mu \mathrm{m}$ 
thick) of each block was stained with hematoxylin and eosin and used for the morphological study.

For the ultrastructural study, small randomly selected samples were primarily fixed in a $2 \%$ glutaldehyde solution in $0.1 \mathrm{M}$ phosphate buffer (pH 7.4) overnight at $4{ }^{\circ} \mathrm{C}$ and then refixed in $1 \%$ osmium tetroxide in $0.1 \mathrm{M}$ phosphate buffer $(\mathrm{pH}$ 7.4) for $30 \mathrm{~min}$. After dehydration in graded ethanol series and embedding in Araldite, semi-thin and ultra-thin sections were cut on an LKB ultramicrotome (Central Microscopy Research Facilities, University of Córdoba, Spain). Ultra-thin sections were double-stained with uranyl acetate and lead citrate. For the scanning study, the sample was critical point dried and then coated in colloidal gold. Ultra-thin sections were viewed and photographed in a JEM 1400 transmission electron microscope.

\section{Morphometric study}

The morphometric studies of the prolactin cells were done directly on images taken of the cephalic lobe of the pituitary gland under the electron microscope, quantifying both the number and size of the cells. 20 small squares/ animal were quantified so that 100 squares/group were counted, each grid square being $100 \pi \mathrm{m}$ per side, so that the totality of the surface $10 \times 10=$ $100 \mathrm{~nm}^{2}$, the total surface analyzed/group being of $100 \times 100=10000 \mathrm{~nm}^{2}$. We based ourselves on cell identification by the pleomorphism of granules, measuring the nucleus surface so that we obtained the number of cells observed on that surface.

The morphometric studies of the chloride cells were made by optical microscope magnified to $\mathrm{x} 40$. Chloride cells were counted by measuring the nucleus of the five different preparations per animal (H\&E).

\section{Statistical analysis}

Data were analyzed using the statistical program Statgraphic Centurion XVI ${ }^{\circledR}$, to determine BPA effects on every exposed group. ANOVA (test-F) was used to demonstrate whether there were any significant differences between the averages. The Fisher LSD post hoc test was performed on multiple comparisons between groups. Results are expressed as mean values \pm standard deviation (SD) and $P<0.05$ was considered to be significant.

\section{RESULTS}

In the control group, the prolactin cells were distributed jointly with the adenocorticotropic hormones throughout the zebrafish posterior and anterior pituitary gland. Prolactin cells were elongated in shape, with scant cytoplasmic prolongations, and they were near the capillaries (Fig. 1A). Their nucleus, spherical and oval in shape, was arranged in the center of the cell, with a thin chromatin and a developed nucleolus. This cell had abundant organoids, such as the rough reticulum and especially the Golgi complex, as well as proliferous mitochondria. These prolactin cells displayed secretion granules, which tended to be laid out near the nucleus relating themselves to the Golgi complex (Fig. 1B). However, their differential characteristic was their strong pleomorphism, which made the prolactin cells unmistakable in relation to the different pituitary gland cells. These granules came in different shapes, i.e. spherical, ovoid and with a branched contour.

In the analysis of the gills of the control group, the layout of the apparently normal primary and respiratory lamellae was observed as having large acidophilic chloride cells, these being found preferably in the basal zones of the respiratory lamellae (Fig. 2A, 2B, 3A, 3B).

In the exposure group of $1 \mu \mathrm{g} / \mathrm{L}$ of BPA, when evaluating the pituitary gland, we observed that the prolactin cells morphology was similar to that of the cells in the control group with regard to their configuration and distribution in the anterior lobe of the gland (Fig. 1A). They appeared in an isolated manner of between spherical and ovoid in shape. The images observed corresponded to a very active endocrine cell with a broad Golgi complex and a very abundant rough reticulum. The granules were seen to be highly pleomorphic and numerous, although the most pleomorphic ones were located as being related 

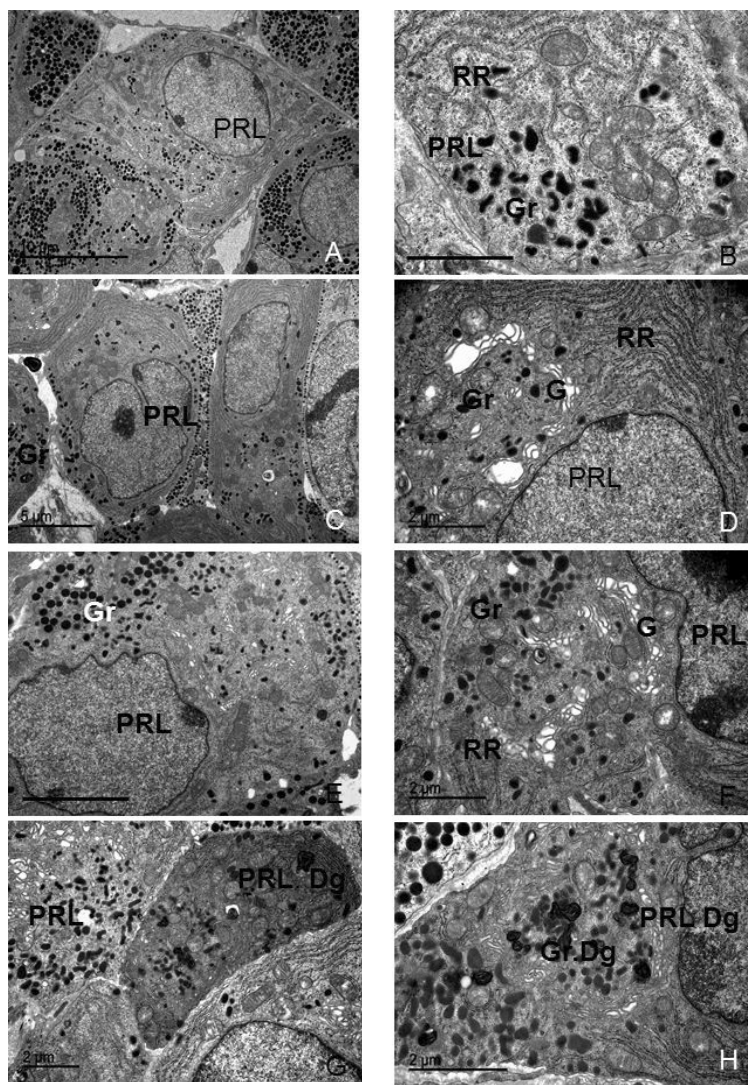

Fig. 1. Ultrastructural observations of the pituitary gland. A. Control and $1 \mu \mathrm{g} / \mathrm{L}$ group. Prolactin cell (PRL), with a stellate morphology, a large nucleus and a cytoplasm with abundant organoids and secretion granules.

B. Control and $1 \mu \mathrm{g} / L$ group. Detail of (PRL). A rough reticulum $(R R)$ and grouped and highly pleomorphic secretion granules (Gr) stand out.

C. $10 \mu \mathrm{g} / \mathrm{L}$ group. Prolactin cell (PRL), oval-shaped with a clear nucleus, organoids and pleomorphic granules $(G r)$ in a large amount.

D. $10 \mu \mathrm{g} / \mathrm{L}$ group. Detail of a very active Prolactin cell (PRL). A sizeable rough reticulum (RR) and Golgi complex $(G)$ are prominent, and there is especially an increase in dense, pleomorphic secretion granules $(G r)$. E. $100 \mu \mathrm{g} / \mathrm{L}$ group. A highly developed prolactin cell (PRL) with an eccentric nucleus and abundant organoids and secretion granules $(\mathrm{Gr})$.

F. $100 \mu \mathrm{g} / L$ group. Detail of Prolactin cell (PRL), which shows a great development of its organoids, of the Golgi complex $(G)$ and rough reticulum (RR). It has abundant highly pleomorphic granules $(G r)$.

G. $1000 \mu \mathrm{g} / L$ group. Two types of Prolactin cell (PRL) can be seen, on one hand a group which is similar to the activated cells (PRL) the other, the degenerated Prolactin cell (PRL Dg), both nucleus and cytoplasm are dense, and it is noteworthy that a large number of its granules are in crynophagy (self-destruction).

H. $1000 \mu \mathrm{g} / \mathrm{L}$ group. Detail of prolactin cell (PRL Dg), with most of its granules in autophagocytosis (GrDg).
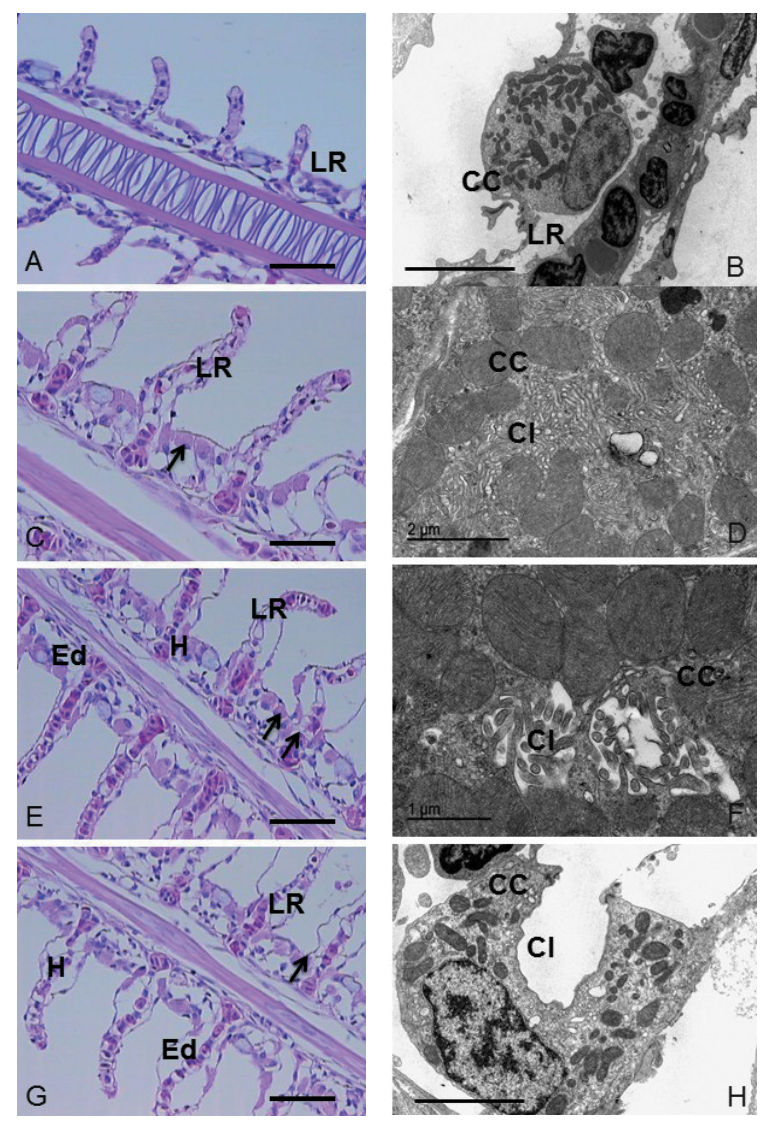

Fig. 2. A, C, E, G: A photomicrograph of gills stained with $H \& E \times 40 . B, D, F, H$ :

Ultrastructural observations

A. Control and $1 \mu \mathrm{g} / \mathrm{L}$ group. Detail of gill under optical microscope, with normal respiratory lamellae (LR) and chloride cells (CC) in basal zone.

$B$. Control and $1 \mu \mathrm{g} / L$ group. Detail of respiratory lamellae (LR) under transmission electron microscope (T.E.M). The presence of a chloride cell (CC) with abundant mitochondria should be noted.

C. $10 \mu \mathrm{g} / \mathrm{L}$ group. Detail of respiratory lamellae (LR). The acidophilous chloride cells (arrow) and vascular hyperaemia can be seen.

D. $10 \mu \mathrm{g} / \mathrm{L}$ group. Detail of chloride Cell (CC) under T.E.M. The intracellular canaliculus (CI) with numerous microvilli and mitochondria $(M)$ standing out.

E. $100 \mu \mathrm{g} / \mathrm{L}$ group. Detail of gill. There are numerous chloride cells (arrow) and vascular alterations with oedema (Ed) and hyperaemia $(H)$.

F. $100 \mu \mathrm{g} / \mathrm{L}$ group. Detail of chloride Cell (CC) under T.E.M. A dilated intracellular canaliculus (CI) is highlighted.

G. $1000 \mu \mathrm{g} / \mathrm{L}$ group. Detail of respiratory lamellae (LR). There are numerous chloride cells with hyperaemic membrane $(H)$ and oedema $(E d)$.

H. $1000 \mu \mathrm{g} / \mathrm{L}$ group. Detail of chloride Cell (CC) under T.E.M. A dilated intracellular canaliculus (CI) and loss of microvilli stand out. 

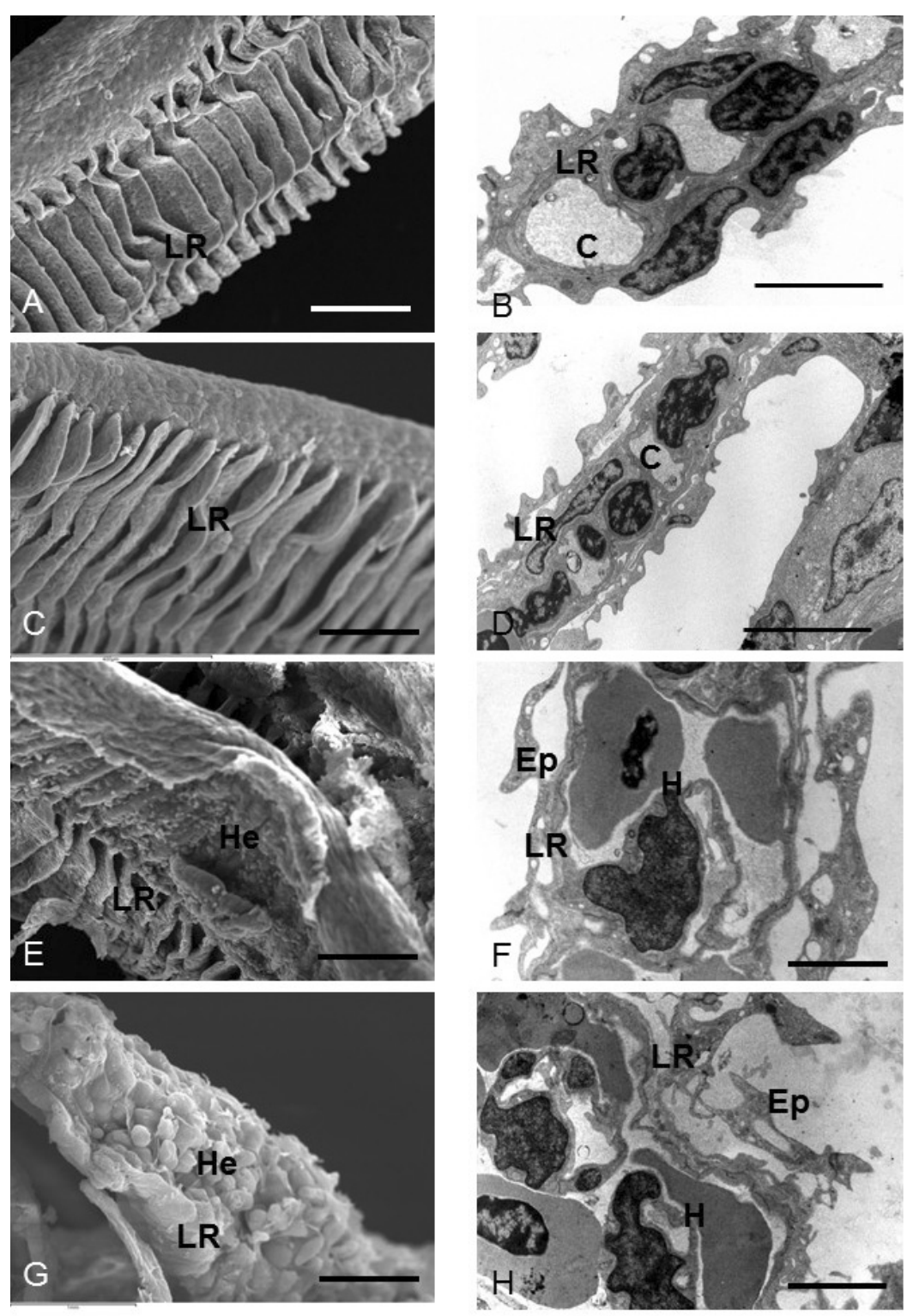

Fig. 3. Gill images from the study groups. A, C, E, G: scanning electron microscopy (S.E.M.) B, D, F, H: Transmission Electron Microscopy (T.E.M.).

A. Control and $1 \mu \mathrm{g} / \mathrm{L}$ group. Detail of gill under S.E.M The normal and uniform respiratory lamellae (LR) are notable.

B. Control and $1 \mu \mathrm{g} / \mathrm{L}$ group Detail of respiratory lamellae (LR) under T.E.M. The presence of normal capillaries (C) stands out.

C. $10 \mu \mathrm{g} /$ L group. Detail of gill under S.E.M. Swollen respiratory lamellae (LR) are seen.

D. $10 \mu \mathrm{g} / \mathrm{L}$ group. Detail of respiratory lamellae (LR) under T.E.M. Capillaries $(C)$ with dilated lights and the presence of red blood cells are notable.

E. $100 \mu \mathrm{g} / \mathrm{L}$ group. Detail of gill under S.E.M. Disorganization of the respiratory lamellae (LR) with haemorrhages (He) is observed.

F. $100 \mu \mathrm{g} / \mathrm{L}$ group. Detail of respiratory lamellae (LR) under T.E.M. Disorganization of the hyperaemic capillaries (H) and of the epithelium (Ep) are prominent.

G. $1000 \mu \mathrm{g} / \mathrm{L}$ group. Detail of the gill under S.E.M. There is a disorganization of the respiratory lamellae (LR), with partial loss of coating and accumulations of red blood cells (He).

H. $1000 \mu \mathrm{g} / \mathrm{L}$ group. Detail of respiratory lamella under T.E.M. A disorganization of the respiratory lamellae (LR) with highly dilated and hyperaemic capillaries $(H)$ and a loss of the coating epithelium (Ep) stands out. 
Table 1. Number and size of prolactin and chloride cells in zebrafish exposed to different BPA concentrations (mean $\pm S D)$

\section{Study Groups}

\begin{tabular}{llllll} 
& & $\begin{array}{l}\text { Control and } \\
\mathbf{1} \boldsymbol{\mu g} / \mathbf{L}\end{array}$ & $\mathbf{1 0} \boldsymbol{\mu g} / \mathbf{L}$ & $\mathbf{1 0 0} \boldsymbol{\mu g} / \mathbf{L}$ & $\mathbf{1 0 0 0} \boldsymbol{\mu g} / \mathbf{L}$ \\
\hline \multirow{2}{*}{ Chloride Cells } & Number & $3.46 \pm 0.76$ & $5.44 \pm 0.70^{*}$ & $7.05 \pm 0.86^{*}$ & $5.82 \pm 0.79^{*}$ \\
& Size $(\boldsymbol{\mu m})$ & $19.29 \pm 3.59$ & $27.85 \pm 1.54^{*}$ & $30.26 \pm 2.75^{*}$ & $30.42 \pm 4.17^{*}$ \\
\multirow{2}{*}{ Prolactin Cells } & Number & $1.93 \pm 0.51$ & $2.60 \pm 0.71$ & $3.03 \pm 0.39^{*}$ & $2.69 \pm 0.38^{*}$ \\
& Size $(\boldsymbol{\mu m})$ & $15.63 \pm 1.19$ & $17.45 \pm 1.02^{*}$ & $21.11 \pm 1.94^{*}$ & $19.85 \pm 1.19^{*}$ \\
\hline
\end{tabular}

Significantly different from the Control and $1 \mu \mathrm{g} / \mathrm{L}$ groups with $p<0.05$.

to the Golgi complex, with the granules situated close to the cell membrane (Fig. 1B).

In the histopathological study of the gills in this first exposure group, we hardly found any morphological alterations either in the primary lamellae or in the respiratory ones. Similarly, this occurred with the chloride cells, which in addition appeared as forming cup-shaped and acidophilic cells (Fig. 2A, 2B).

In the $10 \mu \mathrm{g} / \mathrm{L}$ group during the evaluation of the pituitary gland, it was observed how the prolactin cells of this group differed from those of the control. They presented granules in two places: first, those located in relation to the Golgi complex which were pleomorphic (this is a characteristic of this type of cell) and, second, the granules in the peripheral areas, which were very numerous, spherical and highly electron-dense. The prolactin cells had an ovoid nucleus. These cells had highly developed organoids, especially the Golgi complex, the endoplasmic or rough reticulum and mitochondria (Fig. 1C, 1D).

During the gill analysis, the initiation of its alterations was observed, with vascular modification in the lamellae, most of their capillaries being hyperemic (Fig. 2C, 2D, 3C). The chloride cells were also seen to be affected by an increase in number (Table 1), and above all an increment in size, but maintaining a uniform stain intensity (Fig. 2C, 3D).

The animals exposed to $100 \mu \mathrm{g} / \mathrm{L}$ of BPA displayed prolactin cells with two functionally different shapes. First, very similar ones to those of the previous group with a decline in granule density, with the development of their cytoplasmic organoids that participated directly in the formation of granules (Fig. 1E, 1F).

Second, one shape was characterized morphologically by being an endocrine cell with abundant granule-forming organoids, these granulations being very abundant, pleomorphic and electron-dense, occupying a large part of the cell. However, what defines these cells was the existence of autophagosome as myelin figures, which were fundamentally formed of more central granules, and which led one to think of a self-destruction of the hormone within the granulation.

In this study group, some very serious vascular alterations were found in the whole gill area. The alterations were in the vascular bed, with a generalized hyperemia, with a prominent edema, which arrived at separating the lining epithelium from the respiratory lamellae, with the vascular bed. There was an increase in the number of chloride cells; the acidophilus was maintained, also showing a clearer and vacuolated cytoplasm (Fig. 2E, 2F, 3E, 3F).

Finally, the animals exposed to the highest concentration of BPA $(1000 \mu \mathrm{g} / \mathrm{L})$, exhibited prolactin cells also of two different types, but which were more defined; on the one hand, apparently functional cells, and a second type which not only modified its secretion granules but began to show morphological signs of cells in a degeneration process.

The active endocrine pituitary gland cells exhibited an important development in their granulations, these being pleomorphic and electron-dense and showing an abundant growth of the rough endoplasmic reticulum, Golgi complex and mitochondria (Fig. 1G, 1H). 
The second type of prolactin cell corresponded to degenerative or regression phases of these cells. First, an increase in the electron density of all their components, cytoplasm and nucleus stood out. These modifications were preferably prominent in the cytoplasm, showing dilations of the Golgi complex and the rough endoplasmic reticulum, together with a hyalinization of the cell matrix. There were swellings in the mitochondria with a partial loss of the mitochondrial crests. In addition, as mentioned in the previous group, although abundant dense, pleomorphic granules were maintained, many of them were affected by crynophagy phenomena, which presented themselves as autophagosomes or myelin figures (Fig. 1G, H).

Finally, at gill level, the alterations appearing in this last experiment group were still more evident, both the vascular and ionic regulation ones. All the blood vessels were found to be hyperemic, highlighting the edema, which affected both the primary and the respiratory lamellae. The size of the chloride cells was increased, with a vacuolization in all of the cytoplasm standing out (Fig. 2G, 2H, 3G, 3H).

\section{Quantitative study}

The data resulting from the optical and electron microscopic quantifications have been included in Table 1. The data obtained from the control group and $1 \mu \mathrm{g} / \mathrm{L}$ were considered all together as their quantified values were equal.

The prolactin cells were quantified under the electron microscope (Table 1). We observed an increase in the number of cells in the 10 and $100 \mu \mathrm{g} / \mathrm{L}$ groups, with significant differences $(p<0.05)$ in the $100 \mu \mathrm{g} / \mathrm{L}$ group with respect to the control and the first exposed group. This significant difference was also observed in the last study group compared to the control although it displayed a drop in the number of cells. No significant differences were obtained between the treated groups.

There was an increase in the mean diameter of the prolactin cells in the groups exposed to 10 and $100 \mu \mathrm{g} / \mathrm{L}$, which was evident in the 100 $\mu \mathrm{g} / \mathrm{L}$ group, while in the $1000 \mu \mathrm{g} / \mathrm{L}$ group the mean diameter decreased. All the treated groups showed significant differences with respect to the control $(p<0.05)$, and between each other, with no significant differences being obtained between the 10 and $100 \mu \mathrm{g} / \mathrm{L}$ groups.

In the chloride cell quantification (Table 1), in the 10 and $100 \mu \mathrm{g} / \mathrm{L}$ groups, an increase in the cell number was noted with significant differences $(p<0.05)$ in both cases with respect to the control and the first exposure group. This increase fell in the group with the highest concentration $(1000 \mu \mathrm{g} / \mathrm{L})$ although significant differences were still maintained compared to the control.

With regard to the nucleus size of the chloride cells, all the groups treated (except for that of $1 \mu \mathrm{g} / \mathrm{L}$ ) displayed significant differences $(p<0.05)$, with respect to the control but no significant differences, were obtained between the treated groups.

\section{DISCUSSION}

Zebrafish are one of a group of small fish species that can be kept in the laboratory. They are easily exposed to endocrine-disrupting chemicals in tank water at different stages in their life cycle and exhibit measurable sensitivity to endocrine-disrupting chemicals, including sexual dimorphism (VAN DEN BELT et al., 2001; ORN et al,. 2003; McGONNELL et al., 2006).

Low-dose effects of endocrine-disrupting chemicals such as BPA are mediated by endocrine-signaling pathways that have evolved to act as powerful amplifiers, with the result that important changes in cell function can occur in response to extremely low concentrations (WELSHONS et al., 2003).

The action of the BPA as a neuroendocrine disruptor has been widely studied (MOLINA et al., 2013; JEDEON et al., 2016; RHAMAN et al., 2016). Due to its importance as an environmental and fundamentally aquatic pollutant, in this work, we proposed to evaluate its effects on ionic regulation in fish, by studying their chloride and prolactin cells.

To understand what happens in the pituitary gland cells, in this work it was first necessary to analyze what goes on in the gills. As reported by 
MARCATO et al. (2014), endocrine disruptors affect the gill system and, consequently, its ionic regulation. Gill surfaces are in direct and permanent contact with water contaminants and are therefore suitable markers for aquatic pollution (BERNET et al., 1999). Fish gills show limited responses to a wide range of environmental physicochemical stimuli; and, accordingly, they are considered to be general but nonspecific biomarkers. Thus, quantifying the tissue damage extension is necessary in order to gain information about potential compensatory reserves and their influence on fish homeostasis (MANERA et al., 2016). BPA seriously affects the respiratory system of fish and their ionic regulation. A continuous treatment with this compound could trigger progressively evident and serious lesions in the gills, although it should be remembered that pituitary and gonad affectation caused by endocrine disruptors could favor gill alterations. Therefore, both facts are closely related.

On analyzing the prolactin cells, we observed that their granulations were the components marking cell depletion due to a lack of activity in the chloride cells, which they regulate. These cells behave like all endocrines as they store large amounts of hormones in their granules, which they are not able to use. A degradation is produced in the secretion granule itself, namely crynophagy or autolysis, which is probably the reason for our having observed numerous, large autophagosomes in the groups with the highest exposure concentration. There was an increase in the number of chloride cells in the (10 and 100 $\mu \mathrm{g} / \mathrm{L})$ group due to hyperplasia but they dropped in the $1000 \mu \mathrm{g} / \mathrm{L}$ BPA group, probably due to depletion. Our results coincided with those of other authors who, after exposure to BPA, also described edema, hyperplasia and hypertrophy images (BARIŠIĆ et al., 2015; FAHEEM et al., 2016), in which damage increased with increasing concentrations of heavy metals and BPA, respectively. In relation to chloride cell size in the (10 and 100 $\mu \mathrm{g} / \mathrm{L})$ groups, it increased due to the dilation of the intracellular canal, which was maintained in the $1000 \mu \mathrm{g} / \mathrm{L}$ exposure group, in which there was a total dilation probably due to depletion, which would end up causing the loss of its func- tionality from excessive dilation. ELSHAER et al. (2013) observed cell necrosis after exposure to $50 \mu \mathrm{g} / \mathrm{L}$ BPA for 15 days, subsequently observing necrosis in the secondary gill lamellae after 30 days of treatment. The progressive changes, such as hyperplasia and hypertrophy of epithelial cells, may increase epithelial thickness, which widens the distance between external environment and the blood, retarding or preventing the entry of toxic ions into the blood stream. This could be considered as being general safety measures against toxicants (ELSHAER et al., 2013; BARIŠIĆ et al., 2015).

Pituitary gonadotropin cells play a crucial role in the central regulation of the reproduction of most vertebrates. However, they can be seriously modified by endocrine disruptors and may be one of the reasons for infertility produced by these compounds. Possible modifications of prolactin cells are little known in these exposure concentrations, although their participation in pathological processes has been reported (WISNIEWSKY et al., 2015). The reactions and evolutions of the prolactin cells were highly significant and evolved in parallel to the alterations described in gills. Thus, the reactive hypertrophy and hyperplasia processes on one hand, and atrophy and hypoplasia on the other, with which the prolactin cells terminate (GOLOUBKOVA et al., 2000, VELASCO-MARINERO et al., 2011), correspond to the phases, first, of the cell activations, and, second, the degeneration processes of the gill cells. From these events, it can be deduced that, in a first instance, BPA tends to alter the gill system, and this reacts by activating the chloride cells, which are enhanced by the hormonal action of the prolactin cells. When exposure to BPA is at higher concentrations (100 and $1000 \mu \mathrm{g} / \mathrm{L})$, a defensive depletion of the gills is produced due to severe circulatory alterations and degradation of the chloride cells, making their pituitary regulation impossible, which could be considered as being the main cause of the functional inversion of the prolactin cells.

The activation of the prolactin cells is defined by a hypertrophy, which is due to a generalized increase in all the cell components, to a nuclear increase and, especially, to a greater develop- 
ment of their metabolic organoids, which results in a larger amount of secretion granules. Curiously enough, the granulation activation was not only expressed by the increase in their number, but also by profound changes in their morphology. We have therefore described the pleomorphic granules as being in direct relation to the Golgi complex, and large deposits of large, spherical, dense granules in large amounts on the cytoplasmic periphery. In the quantification of the prolactin cells there was a significant increase $(p<0.05)$ in their number in the exposure groups of 10 and $100 \mu \mathrm{g} / \mathrm{L}$ of BPA due to hyperplasia, differing from what was observed in a study on rats in which the number of prolactin cells was seen to be modified, although not significantly (VELASCO-MARINERO et al., 2011). There was an increase in the mean diameter in groups (10 and $100 \mu \mathrm{g} / \mathrm{L})$, which was more evident in the 100 $\mu \mathrm{g} / \mathrm{L}$ group due to hypertrophy, and a diminution in size in the $1000 \mu \mathrm{g} / \mathrm{L}$ group, probably because it did not receive any hormonal stimulus from the testicles, thus inducing a decrease in the secretion capacity, producing autophagy.

\section{CONCLUSIONS}

In conclusion, our results indicated that exposure to BPA caused changes in chloride cells, which were intensified as the exposure concentration dose increased. Those modifications triggered a series of alterations in prolactin cells, which were aimed at compensating the chloride cell hypofunctionality. Prolactin cells showed modifications in order to maintain an adequate gill functioning and, thus, guarantee ionic regulation. In groups with the highest BPA concentrations, the circulatory alterations and chloride cell degradation were so severe that prolactin cell compensation was made impossible. The impossibility of prolactin cell compensation is the main cause of the functional involution at pituitary level leading the ionic regulation affected.

\section{ACKNOWLEDGEMENTS}

The authors wish to thank the Spanish Junta de Andalucía (P09-AGR-514) for their financial support for this study.

The authors are grateful to the Institud für Pathologie Stiftung Tieräzliche Hochschule Hannover (Germany), especially Dr Wolfgang BAUMGÄRTNER and the electron microscopy technician, for their encouragement during the ultrastructural image evaluation.

\section{REFERENCES}

BARIŠIĆ, J., Z. DRAGUN, S. RAMANI, V. FILIPOVIĆ MARIJIĆ, N. KRASNIĆI, R. ČOŽ-RAKOVAC, V. KOSTOV, K. REBOK \& M. JORDANOVA. 2015. Evaluation of histopathological alterations in the gills of Vardar chub (Squalius vardarensis Karaman) as an indicator of river pollution. Ecotox Environ Saf., 118: 158-166.

BARTELS, H., M. DOCKER, M. KRAPPE, M. WHITE, C. WREDE \& I. POTTER. 2015. Variations in the presence of chloride cells in the gills of lampreys (Petromyzontiformes) and their evolutionary implications. J. Fish Biol., 86: 1421-1428.

BERNET, D., H. SCHMIDT, W. MEIER, P. BURKHARDTHOLM \& T. WAHLI. 1999. Histopathology in fish: proposal for a protocol to assess aquatic pollution. J. Fish Dis., 22: 25-34.

BHANDARI, R., S. DEEM, D. HOLIDAY, C. JANDEGIAN, C. KASSOTIS, S. NAGEL, D. TILLITT, F. VOM SALL \& C. ROSENDELD. 2015. Effects of the environmental estrogenic contaminants bisphenol A and 17 $\alpha$-ethinyl estradiol on sexual development and adult behaviors in aquatic wildlife species. Gen Comp Endocrinol., 214: 195-219

ELSHAER F.M., A. WALID, A. ABU-SHAEIR \& S. A. BAKRY. 2013. Histopathological changes in the kidney of mosquito fish, Gambusia Affinis and guppy fish, Poecilia reticulate exposed to Bisphenol A. Egypt. J. Aquat. Biol. 
\& Fish., 17(4):83- 93.

FAHEEM, M., N. JAHAN \& K.P. LONE. 2016. Histopathological effects of bisphenol-A on liver, kidneys and gills of Indian major carp, Catla Catla (Hamilton, 1822) J. Anim. Plant Sci., 26(2): 514-522

FITZGERAKD, R.E. \& M.F. WILKS. 2014. Bisphenol A-Why an adverse outcome pathway framework needs to be applied. Toxicol lett., 230: 368-374.

GOLOUBKOVA, T., M. RIBEIRO, L. RODRIGUES, A. CECCONELLO \& P. SPRITZER. 2000. Effects of xenoestrogen bisphenol A on uterine and pituitary weight, serum prolactin levels and immunoreactive prolactin cells in ovariectomized Wistar rats. Arch. Toxicol., 74: 92-98.

HASSANIN, A., S. KUWAHARA, NURHIDAYAT, Y. TSUKAMOTO, W. OGAWA. K. HIRAMATSU \& F. SASAKI. 2002. Gonadosomatic Index and Testis Morphology of Common Carp (Cyprinus carpio) in Rivers Contaminated with Estrogenic Chemicals. J. Vet. Med. Sci., 64: 921-926.

HOWDESHELL, K.L., P.H. PETERMAN, B.M. JUDY, J.A. TAYLOR, C.E. ORAZIO, R.L RUHLEN, F.S. VOM SAAL \& W.V. WELSHONS. 2003. Bisphenol $\mathrm{A}$ is released from used polycarbonate animal cages into water at room temperature. Environ. Health Perspect., 111:11801187.

INOKUCHI, M., J. BREVES, S. MORIYAMA, S. WATANABE, T. KANEKO, D. LERNER, E. GRAU \& A. SEALE. 2015. Prolactin 177, prolactin 188, and extracellular osmolality independently regulate the gene expression of ion transport effectors in gill of Mozambique tilapia. Am. J. Physiol. Regul. Integr. Comp. Physiol., 309(10): 1251-1263.

JEDEON, K., A. BERDAL \& A. BABAJKO. 2016. Impact of three endocrine disruptors, Bisphenol A, Genistein and Vinclozolin on female rat enamel. Bull. Group Int. Rech. Sci. Stomatol. Odontol., 53(1):e28.

LANG, I.A., T.S. GALLOWAY, A. SCARLETT, W.E. HENLEY, M. DEPLEDGE, R.B. WALLACE, \& D. MELZER. 2008. Association of urinary bisphenol A with medical disorders and laboratory abnormalities in adults. JAMA., 300(11): 1303-1310.

MANERA, M., L. GIARI, J.A. DEPASQUALE \& B.S. DEZFULI. 2016. European sea bass gill pathology after exposure to cadmium and terbuthylazine: expert versus fractal analysis $\mathrm{J}$. Microsc., 261(3): 291-299.

MARCATO, A.C., A.T. YABUKI \& C.S. FONTANETTI. 2014. Nickel exposure promotes osmoregulatory disturbances in Oreochromis niloticus gills: histopathological and energy dispersive spectrometry analysis. Environ. Sci. Poll. Res. Int., 21:13095-102.

MCGONNELL, I.M. \& R.C. FOWKES. 2006. Fishing for gene function - endocrine modelling in the zebrafish. J. Endocrinol., 189: 425-439.

MOHAMMED, F., F. ELSHAER, H. KHALAF-ALLAH \& S. BAKRY. 2013. Histopathological alterations in gills of some poecilid fishes after exposure to bisphenol-A. World J Fish Mar Sci., 5(6): 693-700.

MOLINA, A., A. LORA, A. BLANCO, J. MONTERDE, N. AYALA \& R. MOYANO, 2013. Endocrine-active compound evaluation: Qualitative and quantitative histomorphological assessment of zebrafish gonads after bisphenol-A exposure. Ecotox Environ Safe., 88:155-162

OECD. 1992. OECD Guidelines for testing of chemicals: Fish, early life stage toxicity test, Section 2, Guideline 210. 24 pp.

OECD. 1993. OECD Guidelines for testing of chemicals: Fish, prolonged toxicity test: 14-day-study, Section 2, Guideline 204. 2 pp.

OECD. 1998. OECD Guidelines for testing of chemicals: Fish, short-term toxicity test on embryo and sac-fry stages, Section 2, Guideline 212, 20 pp.

ORN, S., H. HOLBECH, T. MADSEN, L. NORRGREN, \& G. PETERSEN. 2003. Gonad development and vitellogenin production in zebrafish (Danio rerio) exposed to ethinylestradiol and methyltestosterone. Aquat. Toxicol., 65(4): 397-411.

PIERCE, A., B. FOX, L. DAVIS, N. VISITACION, T. KITAHASHI, T. HIRANO \& E. GRAU. 2007. Prolactin receptor, growth hormone receptor, and putative somatolactin receptor in Mozam- 
bique tilapia: Tissue specific expression and differential regulation by salinity and fasting. Gen. Comp. Endocrinol., 154(1-3): 31-40.

RAMOS, J., J. VARAYOUD, L. KASS, H. RODRIGUEZ,

L. COSTABEL, M. MUÑOZ-DE-TORO, \& E. LUQUE. 2003. Bisphenol A induces both transient and permanent histofunctional alterations of the hypothalamic-pituitary-gonadal axis in prenatally exposed male rats. Endocrinology., 144(7): 3206-3215.

RHAMAN, M., W. KWON, P. KARMAKAR, S. YOON \& B. RYU. 2016. Gestational exposure to bisphenol-A affects the function and proteome profile of F1 spermatozoa in adult mice. Environ. Health Perspect., 125(2):238-245. DOI: 10.1289/EHP378

STOKER, T., C. ROBINETTE, B. BRITT, S. LAWS \& R. COOPER. 1999. Prepubertal exposure to compounds that increase prolactin secretion in the male rat: Effects on the adult prostate. Biol. Reprod., 61(6): 1636-1643.
VAN DEN BELT, K., R. VERHEYEN \& H. WITTERS. 2001. Reproductive effects of ethynylestradiol and 4t-octylphenol on the zebrafish (Danio rerio). Arch. Environ. Contam. Toxicol., 41: 458-467.

VELASCO-MARINERO, E., J. HERRERO-PAYO \& J. CARRETERO-GONZALEZ. 2011. Changes in pituitary and prolactin cells of Wistar rats after two dental fillings with bisphenolic resins. Arch. Oral. Biol., 56(6):592-598.

WELSHONS, W. V., K.A. THAYER, B.M. JUDY, J.A. TAYLOR, E.M. CURRAN \& F.S. VOM SAAL. 2003. Large effects from small exposures. I. Mechanisms for endocrine-disrupting chemicals with estrogenic activity. Environ Health Perspect., 111: 994-1006.

WISNIEWSKY, P., R.M. ROMANO, M.M. KIZYS, T. KASAMATSU, G. GIANNOCCO, M.I. CHIAMOLERA, M.R. DIAS-DA-SILVA \& M.A ROMANO. 2015. Adult exposure to bisphenol A (BPA) in Wistar rats reduces sperm quality with disruption of the hypothalamic-pituitary-testicular axis. Toxicology., 329: 1-9.

Received: 29 August 2016

Accepted: 10 January 2017 


\title{
Procjena utjecaja disruptora bisfenola A na ionske regulacije kod Danio rerio kroz ispitivanje njihovih kloridnih i prolaktinskih stanica
}

\author{
María I. BARASONA*, Ana MOLINA*, Alfonso BLANCO, Nahum AYALA \\ i Rosario MOYANO
}

*Kontakte-adresa:ft2moloa@uco.es

\begin{abstract}
SAŽETAK
Bisfenol Aje jedan od kemijskih spojeva koji se najviše proizvodi u svijetu. Najčešće se koristi za dobivanje plastike i posuda za hranu i može djelovati kao ksenoestrogen kod ljudi. S obzirom na rizik izloženosti bisfenolu A iz okoline i prehrane, i u osnovi kao zagađivaču vode. Cilj istraživanja bio je procijeniti moguće učinke na ionsku regulaciju nakon izlaganja bisfenolu A pomoću histopatološke i morfometrijske studije kloridnih i prolaktinskih stanica u Danio rerio kao eksperimentalnog modela.

Dvadesetpet muških jedinki 16 tjedana starih Danio rerio bili su nasumično raspoređeni u pet ispitivanih skupina ( $\mathrm{n}=5 /$ skupina). Kontrolna skupina i četiri skupine bile su dva tjedna izložene koncentracijama od 1, 10, 100 odnosno $1000 \mu \mathrm{g} / \mathrm{L}$ bisfenola A. Nakon ta dva tjedna uzorci njihovih škrga i hipofize su odmah izuzeti za naknadnu patohistološku analizu.

Rezultati su pokazali kako su se, kod prvih ispitivanih skupina, lezije pojavile u kloridnim stanicama, stvarajući kompenzacijske promjene na prolaktinskim stanicama koje su bile dovoljne za održavanje stabilnosti u izmjeni iona. Kako se povećavala koncentracija izloženosti, ozbiljnije histološke modifikacije su se dogodile. Kod skupina s višom koncentracijom (100 i 1000 g/L) lezije su bile tako jake da su prolaktinske stanice prošle kroz određene degenerativne procese, što je vjerojatno spriječilo kompenzacijsko djelovanje na škrgama.
\end{abstract}

Ključne riječi: bisfenol A, Danio rerio, ionska regulacija, prolaktinske stanice, kloridne stanice 